\title{
Does Privatization In Transitional Countries Influence Enterprise Efficiency Growth: A Case Of Croatia And Slovenia
}

Neda Vitezić, (E-mail: nevit@efri.hr), University of Rijeka, Croatia

\begin{abstract}
This paper explores the impact of privatization on the efficiency growth of enterprises in two transitional countries, which did not follow the same privatization model. The aim of this research is to analyze the effects of privatization on micro and macroeconomic indicators. Research will be based on ten-year time-series analysis, using both financial and other indicators. Particular emphasis will be placed on efficiency and profitability growth by analyzing separately large, medium, and small enterprises. The expressed hypotheses, which will be tested through statistical data analysis, are related to the statement that the privatization model utilized did not contribute to the efficiency of the entire economy. However, it did contribute to the efficiency of particular segments of enterprises. The second hypothesis is that the recent growth of small business efficiency will decrease while medium and large enterprise efficiency will increase. Finally, the third hypothesis is related to the impact of enterprise performance in ten years period on macroeconomic indicators. The development of small business in both countries in the early years of transition will be examined. During this time of period, small businesses tended to experience more efficiency growth than other enterprises. However, there currently appears to be a shift in efficiency and profitability growth to medium and large enterprises. Therefore, another aim of this research is to determine what factors may have caused these differences and lead to the opinion about future efficiency growth in countries in transition.
\end{abstract}

\section{INTRODUCTION}

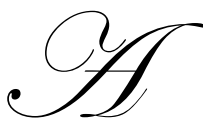

lthough some researchers point out that there is no theory of transition (Havrylyshyn and McGettigan, 1998), there are some crucial elements, which should be contained, in theoretical and practical approach to the transition process. In the period from post-socialist to a market economy there were significant economic, organizational and sociological changes. These changes were the result of changes in ownership, the political system, and the market itself, i.e. reorientation from seller to buyer's market, reallocation of resources from old to new activities as well as restructuring of the firms. In both Croatia and Slovenia all these factors formerly existed through deregulation and liberalization of the political system and ownership laws. On the microeconomic and macroeconomic relations, some changes are also evident: as a consequence of the privatization and liberalization process, a large number of new, mostly small enterprises were created. Generally, the SME sector in transitional countries of East Europe has grown in the last ten to twelve years, as a result of privatization and breakdown of state or social owned enterprises.

In Croatia and Slovenia small enterprises grew rapidly in the first few years of the privatization process, especially in years 1992 to 1997 . The rapid growth is explained by relatively easy entry in the privatization process, economic situation for supply and demand for some goods, increasing unemployment, and advantages of small business, etc. But in the last few years, a decrease in small business growth is evident as well as a slow increase in medium and large sized enterprises, which stagnated earlier. In a free market today they are all faced with the crucial issue of how to create and maintain a sustainable competitive advantage and gain the enterprise net worth. 
In the macroeconomic level some positive changes in GDP and industrial production are evident, but still not enough to satisfy expectation of economic theory and some foreign institution criteria. There are no structural changes in GDP where priority must be given to industrial sector and export. Thus there aren't many companies hiring and unemployment is still high, especially in Croatia.

\section{BACKGROUND AND HYPOTHESES}

In economic theory and practice, one of the most controversial questions whether privatization improves company performance and industry growth, i.e. microeconomic and macroeconomic benefits. In micro economies, privatization is viewed as the potential for greater allocation and productive efficiency and promotion of a stronger role for the private sector (Sachs, Zinnes, Eliat, 2000, page 6). Another view in microeconomic literature (Sappington and Stiglitz, 1987; Shapiro and Willing, 1990) is that under perfect competition, information and complete contracting, publicly owned and privately owned firms would have the same level of performance.

In the literature, the impact of privatization on enterprise performance has been studied extensively (Megginson, W. I., Netter, J. M., 2001, page 321-89), but its effect on growth and other macroeconomic implications are sparse. Relating to the transition process in the last twelve years, there is now respectable literature on that subject especially where large-scale privatization has taken place in former command and social oriented economies. Roland (2000) provides an overview of privatization and firm performance in transition on a theoretical basis. Privatization is based on the premise that it will improve enterprise performance and help countries grow. But the effects are different on aggregate or micro level and dependency of industry structure. In a cross-country aggregate study, Sachs, Zinnes and Eilat (2000, Vol. III) find that privatization does not by itself increase GDP growth, but they suggest that a positive effect is present when privatization is accompanied by in-depth institutional reforms. Applicable to Croatian and Slovenian economy and growth of GDP, it is obvious that institutional reforms (but also more important stabilization, industry restructuring, financial discipline and new investment) are prerequisite for the increasing of macroeconomic indicators.

A survey based on micro data comes up with assessments which range from finding a large variation of outcomes with no systematically significant effect of privatization on performance (Bevan, Estrin, Schaffer, 1999, pages 1-40), to the conclusion that privatization around the world improves firm performance (Megginson and Netter, 2001). The survey concludes with a statement that privatization tends to improve performance (Shirley and Walsh, 2000) and is strongly associated with more enterprise restructuring (Djankov and Murrel, 2000, page 25).

In the beginning of transition, one of the big mistakes was the opinion that privatization would resolve many problems and provide higher efficiency growth of economy. Full gains from privatization require complementary reforms and development of key institutions, but the changes in behavior and thinking with respect to market rules were also very important. In countries of transition, which are in socially or centrally planned economies, the changing of people's behavior, especially management, is crucial. Thus some results, which were expected from the efficiency point, were not achieved, and the goal of this study was to analyze them and make some conclusion about the influence of privatization to the efficiency matter.

Since the aim of this research is to test the empirical impact of privatization on efficiency growth, the premise is that positive effects of privatization on financial performance and productivity of enterprises would be accompanied by rising macroeconomic growth. From the previous research (Vitezić, N., Tearney, M, 1999, 2001, page 2256-2272 and page 2814-2827) about the growth and efficiency of small and medium businesses in Croatia and Slovenia, it was evident that their fast growth in the first year of the privatization process was starting with a tendency toward higher contribution in total industry revenue, net income, employment etc. In the initial years of transition, the growth rate in the number of small enterprises was tremendous with rates of 40 to 70 percent, which later decreased to 3 to 4 percent, and from 1998 until today there was a decrease in the number of small enterprises but at the same time was a slow increase in the number of medium enterprises. The efficiency as well as liquidity and solvency were poor in the initial stages of transition and appear to be much improved today. Today their share in revenue and income is respectable with a slow tendency of increasing. Capital structure is more acceptable with 
the tendency to increase long-term liabilities. Productivity and efficiency are still not on satisfactory levels and are the main problems in today's enterprise performance.

Related to that, expressed hypotheses are:

H1: The privatization model utilized in two countries of transition did not contribute equally to the efficiency of the entire economy.

H2: The recent growth of small business efficiency will decrease while medium and large enterprise efficiency will increase.

H3: Efficiency of enterprises will have impact on macroeconomic growth on a long-term basis.

To confirm or reject the hypotheses, first the differences in the privatization model and industry structure in two countries are explained. Second, privatization contribution to the country's economic performance and enterprise efficiency is analyzed through time-series macro and micro variables. Third, effects of enterprise efficiency on macroeconomic growth are analyzed through statistical methods.

\section{DIFFERENCES IN PRIVATIZATION MODEL}

There are many methods and variations of privatization but for the perspective of Central and Eastern Europe, Brada (1996) recognized four main types: privatization through restitution, privatization through sale of state property, mass or voucher privatization, and privatization from below. Croatian and Slovenian methods are presented in some research (Bennett et others, 2004) as "mixed privatization" model. Authors distinguish "mass privatization"- firms are sold at a zero or nominal price, "full privatization"- sale of firms to outsiders for positive prices, and "mixed privatization"- includes manager-employee buyouts and leased buyouts.

Although Croatian and Slovenian models are classified as mixed model (including manager-employee buyouts and vouchers), these two models have some differences. Slovenia's model of privatization can be divided into a combination of free distribution of shares and commercial privatization. Thus most firms have chosen a) an internal distribution of shares to employees, b) an internal management-employee acquisition, or c) sale of company shares. Also, every company was obliged by law to transfer 40 percent of its ordinary shares to the three state funds, divided as follows: a) 10 percent to the Pension Fund, b) 10 percent to the Compensation Fund, and c) 20 percent to the Development Fund (Privatization Report 1997, page 19). According to this, 40 percent of company equity was going automatically into external ownership, and the remaining 60 percent were allocated into internal distribution of shares to employees, internal management - employee acquisition, and sale of company shares. Also by law, all Slovenian citizens got ownership certificates, which are an important device of free large-scale privatization. There were two main goals inspiring the idea of privatization by certificates: a) to satisfy the criterion of justice in the same social ownership accumulated by the majority of citizens over the years, and b) to solve the problem of foreign buyers becoming majority shareholders (Horvatin, N., Montanheiro, L., 1996, page 135).

In Croatia, the model of privatization was as follows: a) employees (and former employees) of the enterprise had first option to acquire the shares of the transformed company, and then other Croatian citizens were given the opportunity to acquire shares in that company; b) the price at which the shares could be acquired by employees was based on the estimated net book value, with a discount of 20 percent, together with an additional 1 percent discount for each year of employment with the company; and c) the purchase price could be paid in agreed installments over a five-year period. There have been changes in the law. It was permitted that for all the discounted shares, the acquirer had to pay only the first installment or 5 percent of the total purchase price. This created an interim unfavorable cash-flow situation for the companies, i.e., there was no continuing obligation to pay the reminder of the purchase price for the discounted shares. To overcome this, the revised Privatization Law specifically provides that if three consecutive installment payments are missed, then the purchase contract will terminate without notice. The same law extends the payment period to 20 years. The Law also sets the maximum equity ownership of a company's capital by employees, former employees, and other Croatian citizens at 50 per cent. It provides that the remaining 50 percent or more be sold to both domestic and foreign private investors at the bestpriced public tender offer. The strict conditions of tender (bidders were required to pay a deposit of 10 percent of 
the contract price-[increased to 30 percent], within 7 days of an agreement being concluded and the reminder of the price was to be paid within 5 years) led to a reassessment of what priorities would determine a successful bid (Doing Business in Croatia, 1998, page 34). Currently, bids will not be assessed solely on the basis of price but also on the basis of what other benefits it will bring (job preservation, technology transfer, credit-worthiness etc.).

Given legal differences, it must be recognized that Slovenia was the most developed republic in former Yugoslavia, with Croatia second. Differences in industry structure also existed. Slovenia was much more oriented toward the manufacturing industry while in Croatia, in addition to the manufacturing industry, tourism and shipbuilding were major industries. The Slovenian economy had a strong private sector before privatization and many agricultural and service-related industries were in the private sector prior to independence. In the Croatian economy there were large and middle enterprises oriented to the ex-Yugoslavia market. The process of transforming the entire system from a self-managing socialist economy to a market economy caused considerable difficulty in many industries. The industries primarily affected were the larger enterprises, such as the metalprocessing sector, shipbuilding, and other heavy industries that must radically alter their structure. These industries lost their old markets, and their existing technology and managerial skills make it impossible for them to compete successfully in the World market. This has a trickle-down effect and negatively impacts many small enterprises that serve as suppliers to the larger enterprises.

\section{METHODOLOGY AND EFFICIENCY ANALYSES}

This research primarily is based on small, medium, and large enterprise data in industry sector (excludes some small banks, schools, social organizations, etc.) comparable with NACE -Rev.1. The data covers the ten-year period of 1993 through 2002. This period essentially commences with the beginning of the privatization process in Croatia and Slovenia. The approach employed in this research primarily is based on data collected in special agencies in Croatia and Slovenia ${ }^{1}$. All enterprises (large, medium and small) are required to file annual financial statements in accordance with accounting standards. Thus, this research primarily used items from balance sheets and income statements, as well as other macro statistical data collected from different governmental offices. Values of indicators computed for a 10 year-period are expressed in median.

The last 10-12 years of the transitional process in the countries of East Europe, particularly in Croatia and Slovenia, represents the solid base for exploring changes in the business environment, especially in the aspect of the enterprises' performance. Before making a depth analysis, there is a need to emphasize that the Yugoslavian model of economy (Croatia and Slovenia were part of it) were not the same as in centrally planned economies (Soviet and some others). The ownership was "communal" or "social" and firms were managed by labor, so called by the Yugoslav-type labor-managed firm (Jansen, 2003, page 191). Enterprises are permitted to set output prices and to decide what quantity they will produce. The authority to make decisions is delegated through a workers' council to the manager. Thus, the privatization process in both countries, Croatia and Slovenia, had not been as effective as in central economies, but moreover they gave a possibility to individuals to use "socially owned" resources for their own interest.

The system of economy and level of economic development in Croatia and Slovenia before privatization was more similar to market-oriented countries than to the other Eastern Europe and Soviet Union countries. It is well known that the transition process in Eastern Europe was based on the Washington consensus, which was a political agreement between important institutions: the World Bank and International Fund. Some of the basic issues in the consensus-fast privatization, immediate macro stabilization, and quick liberalization was formally accepted, but immediate macro-stabilization and sustaining of financial discipline was something to be considered in the long run. In the case of Croatia, the Washington consensus did not resolve any crucial macroeconomic questions except inflation, which was low and stable the entire period. The basic elements of macroeconomic policy were not at an adequate level until 2000, when there was a shift in political economy in the last three years (supply side economy, aggregate demand, controlled balance). These are some explanations:

\footnotetext{
${ }^{1}$ Agency for payments in Croatia and Slovenia collect financial data at the end of each year from the large, medium, and small enterprises. Data obtained from mandated disclosure are considered reliable.
} 
a) GDP growth started to increase in the first year of privatization stimulated by domestic demand. But, in 1999 the decrease was by 0.9 percent, and GDP was 16.2 percent lower than in 1990.

b) Inflation rates were high in the year before privatization. From 1995 the rate was stable with an average of 4\%. Since 2000's inflation started to slowly increase, concluding with 5.2 per cent in 2002.

c) Unemployment rate is increasing in the whole period of privatization with the rate of 14.8 in the first year of privatization to 23.2 percent in 2002. Privatization did not lead to higher employment but rather the increase of retired people (which is currently around 1 million).

d) Foreign direct investment was in the first year of privatization very low with average of 2.5 percent, with the exception of 7.3 percent in 1999 when some large banks and firms were sold. In 2002, foreign direct investment was 4.4 percent of GDP.

e) State budget deficit was in the first year lower with average of 1.5 percent and is currently around 4.0 percent. The highest rate of 8.2 percent was at the end of the privatization (1999) when budgets should be filled with some revenue and when we adopted a new tax system (VAT).

From the microeconomic aspects, (as was recognized in the theory too), privatization could not be a guarantee of better enterprise performance. In Croatia and Slovenia, after socially managed ownership, the expectation that private individual ownership would have influence on better performing of enterprise was very high. Let's see what privatization causes and what is the result from the efficiency point of view.

At first, the privatization process caused rapid growth of small enterprises as well as some new mediumsized enterprises. Their number surmounts 98 percent and their positive influence in overall economic growth is evident and important. For example, in Croatia, 2002, they contributed over 40 percent of total revenue, 30 percent of net income and 54 percent in total employment. In Slovenia, the share is increased in 2002 and SMEs contributed over 40 percent in total revenue and net income and 49 percent in total employment. In fact, the high increase last year is not the result of newly opened enterprises, but of changes in criteria for ordering small, medium, and large enterprises. Large and some bigger medium enterprises in both countries did not contribute sufficiently in the first seven years of privatization, but from 2000 they started to operate more efficiently. Their share in revenue and income was decreasing from the beginning of privatization till 1998. After that period started a slow growth with significant shift in 2002. On the contrary, in last two years small businesses begin to perform less efficiently producing more losses.

Creating the possibility of setting up a new private business easily had impact on changing the structural industry. New enterprises were registered mostly in trade and service sector. Their share in total industry is over 40 percent in Croatia and over 30 percent in Slovenia. Stable currency and higher demand of supply have an impact on enterprise's introduction to importing goods. Additionally, these conditions mean additional liabilities for small enterprises. Poor equity and thus their dependence on bank loans is expressed through short term liabilities (which are over 66 percent) of total liabilities, i.e. debt ratio is high (average for SME in both countries is 0.61). In both countries, liabilities have an increasing trend which shows that small and medium-sized enterprises are starting with the expansion of production and having problems financing their own production and services. The trend of using long-term loans is higher in Slovenia, and in general liabilities have a more increasing trend compared with Croatia. In both countries, short-term liabilities exceed long-term liabilities by a factor of two.

Liquidity was the main problem in the first year of the privatization process in transitional countries. Nonpayment ability was a crucial problem in Croatia and also in Slovenia, and it is still expressed but not as strong as before. Financial discipline is better in the last few years, especially in small and medium businesses. Liquidity ratios show that there was no ability for the business to meet liabilities with the assets available. In both countries current and quick ratio of SMEs and large enterprises is lower than should normally be (current ratio in CRO is 1.04, and in SLO 1.18; quick ratio is in CRO 0.79, and in SLO 0.89), whereas liquidity of Slovenian enterprises is slightly better.

During the ten-year period liabilities have increased 2 to over 3 times - especially in small and medium enterprises in both countries. There is a significant increase in short liabilities, and in the last few years long-term liabilities, but at the same time equity decreased 40 to 60 percent. Using debt ratio as a leverage indicator, you can 
see that small enterprises in both countries are more leveraged. This leads us to conclude that they have poor financial recourses, and are more dependent on bank loans. Debt ratio, particularly in Croatian medium enterprises, is lower, i.e. the rate is 0.48 and the reason is that medium enterprises still do not operate profitably and are in difficult financial positions caused by a lack of jobs, old technology, inadequately utilizing capacity, and noncompetitiveness in the global market. Industrial production rate is still not on the level before privatization, but annual average rate of growth from 1993 through 2002 in Croatia is 11 percent, and 8.5 percent in Slovenia.

Analyzing enterprise efficiency through turnover ratios, it is evident that assets of the business in both countries are not efficiently being utilized. Total asset turnover is low and a profitable company would typically have an asset turnover of 1.3 to 1.5. In small enterprises, an average is around 1.0 and in medium and large from 0.5 to 0.9 , thus the holding period of current assets is over a year. Low inventory turnover as well as receivables turnover confirm a problem with profitability, especially in Croatia enterprises. The situation is slowly improving in Slovenian enterprises but medium and large enterprises obviously have a problem with repayment, which cause inefficient performance with negative rates of profitability.

Table 1: Efficiency and Profitability Ratios - median values 1993-2002

\begin{tabular}{|l|c|c|c|c|c|c|c|c|}
\hline \multirow{2}{*}{ Enterprise Indicator } & \multicolumn{2}{|c|}{ Small } & \multicolumn{2}{c|}{ Medium } & \multicolumn{2}{c|}{ Large } & \multicolumn{2}{c|}{ Total } \\
\cline { 2 - 9 } & CRO & SLO & CRO & SLO & CRO & SLO & CRO & SLO \\
\hline Total Asset Turnover & 1.06 & 1.01 & 0.71 & 0.89 & 0.48 & 0.75 & 0.75 & 0.88 \\
& & & & & & & & \\
\hline Inventory Turnover & 7.90 & 9.94 & 7.00 & 8.85 & 5.79 & 8.96 & 6.90 & 9.25 \\
\hline Receivables Turnover & 3.64 & 4.08 & 3.92 & 4.78 & 4.42 & 5.11 & 4.00 & 4.66 \\
\hline ROS & -3.03 & 0.22 & -2.34 & -1.45 & -3.03 & -0.38 & -1.86 & -0.28 \\
\hline ROA & -1.32 & 0.20 & -2.02 & -1.21 & -1.32 & -0.28 & -1.16 & -0.03 \\
\hline ROE & -1.75 & 0.58 & -3.50 & -2.15 & -1.75 & -0.48 & -1.99 & -0.06 \\
\hline
\end{tabular}

Source: Computed from financial statements- Agency of payment in CRO and SLO

In the ten year period, most of the enterprises did not perform profitably due to low efficiency of engaging current assets and low liquidity,. Median values for ten years are negative, except in small business, which in the middle of transition were the only ones who operated profitably. In both countries, they contributed 25 to 30 percent in all industry net income. But in the last two years there is a shift in their performance and in Croatia they show losses. Contrary to Croatia, large and middle sized enterprises started a positive performance upswing.

Sales growth is a measurement that is least suspicious to manipulate compared to indicators such as profit. In both countries sales growth is increasing at a similar rate and the highest rate is of large enterprises (55-59 percent), small enterprises ( 25 to 26 percent) and the lowest rate is in middle-sized enterprises (16 to 19 percent). Average year rate of sales in the entire period was 4 to 6 percent. At the same time the average rate of cost of goods was 4 percent. Total revenue exceeded total expenses with average year rate of 4 percent in Croatia and 3 percent in Slovenia. In the 10-year period the income tax rate was changed an average of 25 to 20 percent in both countries.

Although profitability ratios are negative from the perspective of total industry, there are some positive trends in growth of enterprises, which perform with profit. At the same time positive effects are evident in the levels of losses, with total amounts decreasing (CRO) or slightly increasing (SLO). From the year 2000 there is a shift in performance of large enterprises and some middle- sized enterprises, which started to be profitable. 
Figure 1: Micro and macroeconomic indicators for Croatia

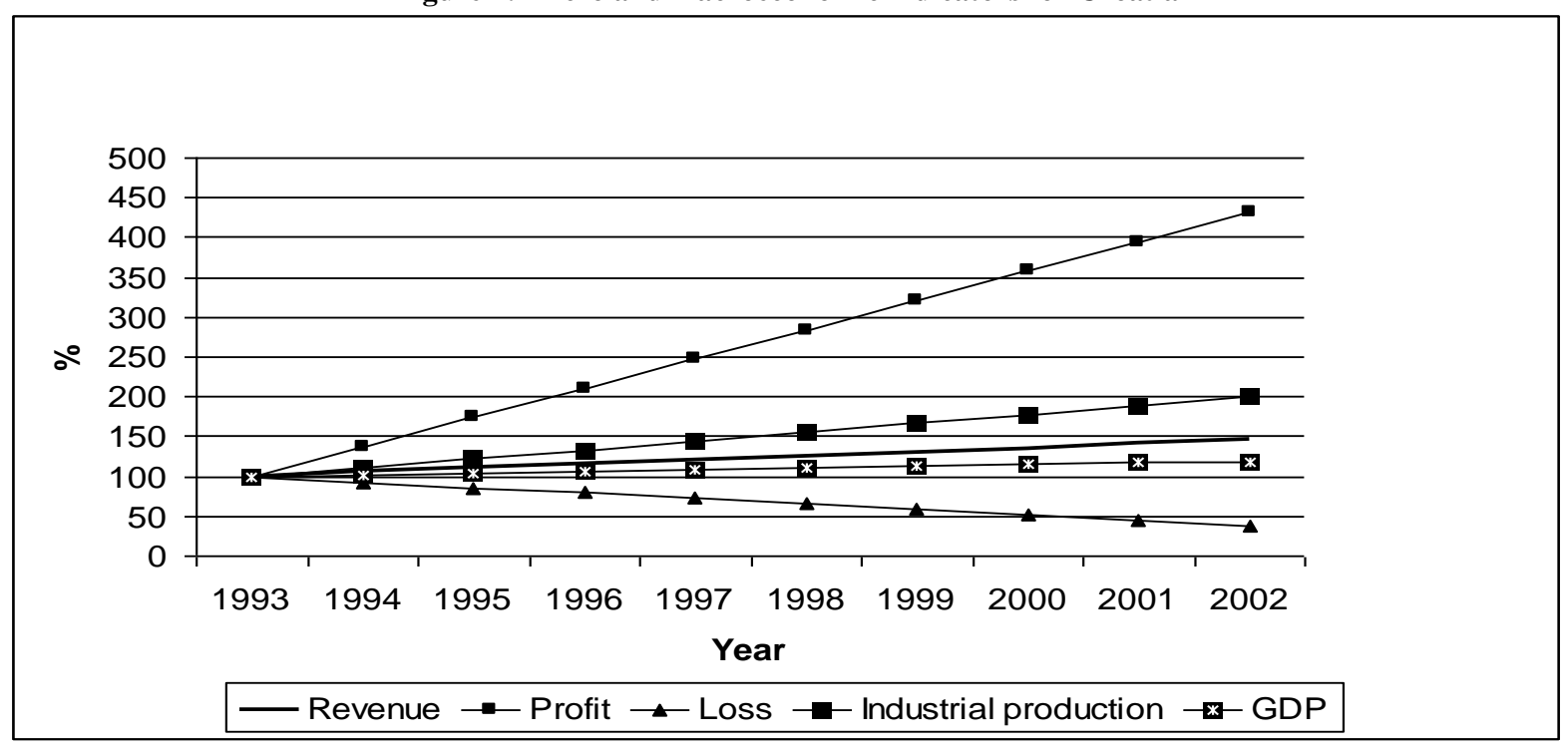

Figure 2: Micro and macroeconomic indicators for Slovenia

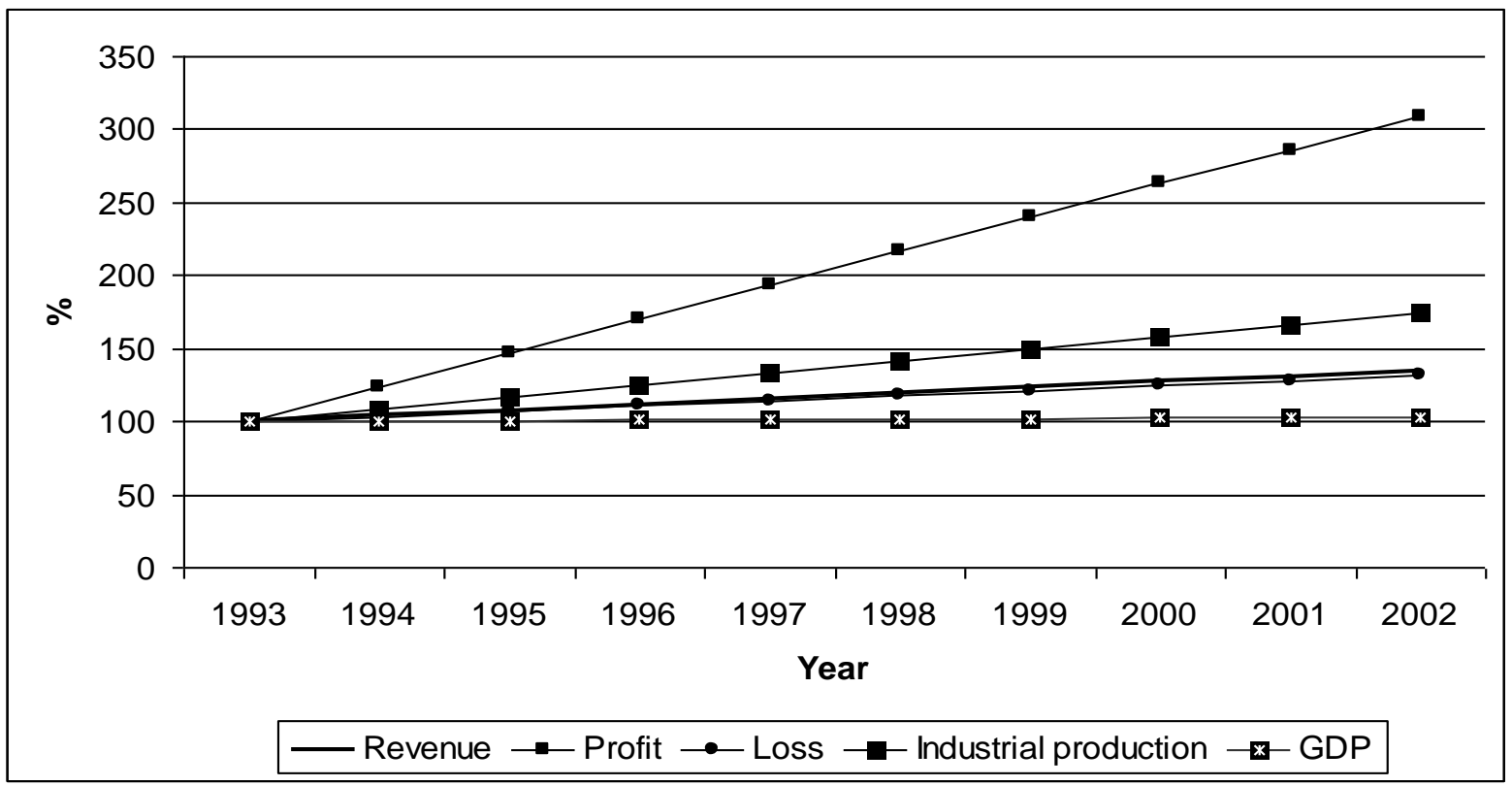

According to the theoretical approach about effects of enterprise financial performance and productivity on macroeconomic growth, the correlation between them is confirmed (between revenue and GDP is 0.79 in CRO and 0.84 in SLO). Average annual rate of GDP growth is 2.1 percent in Croatia and 0.3 in Slovenia for the period of the last ten years. At the same time the average annual rate of revenue is growing by 5 percent in Croatia and 4 percent in Slovenia, and net income growth rate is increasing by 37 percent in Croatia and 24 percent in Slovenia in comparison with 1993. This study confirmed theoretical and other empirical statements about positive effects of privatization on firm performance. In transitional countries this effect did not occur immediately but rather after some period of adjustments to new conditions and other massive economy-wide changes. 


\section{RESULTS}

Through research results based on data in Croatia and Slovenia about impacts of privatization on enterprise efficiency and profitability (as well as on economy as a whole), it is obvious that in the first ten years there were no significant changes compared with the period before privatization. Macroeconomic indicators show that both countries were behind the results before privatization. Not until 2000 did the slow positive shift start by increasing GDP and industrial production. There are still not enough investments in industry as a base of economic development: the tertiary sector is still primary. The causes of inefficient industry in the ten-year period in Croatia could be explained by nonexistent investment policy, directing foreign credit resources to personal and public consumption and foreign direct investment on buying high profitability enterprises. Personal consumption in the past years was 70 percent of GDP with a tendency to decrease in 2002 to 60 percent. However, it is still evident that the share of public consumption is much higher than the share of investment. In other words, we spend more than we produce, i.e. our consumption is $\$ 25$ billion and in the last 13 years Croatia has not achieved $\$ 20$ billion of GDP since the beginning of privatization. (Družić.,G. 2003, page 123). Due to the different industry structures before privatization and independence, GDP in Slovenia is around \$21 billion in 2002 and 26 percent higher than 1990. In Slovenia personal consumption is little lower (50 percent) and higher public consumption ( 20 percent) with the same investment rate as in Croatia.

Figure 2: GDP before and after privatization

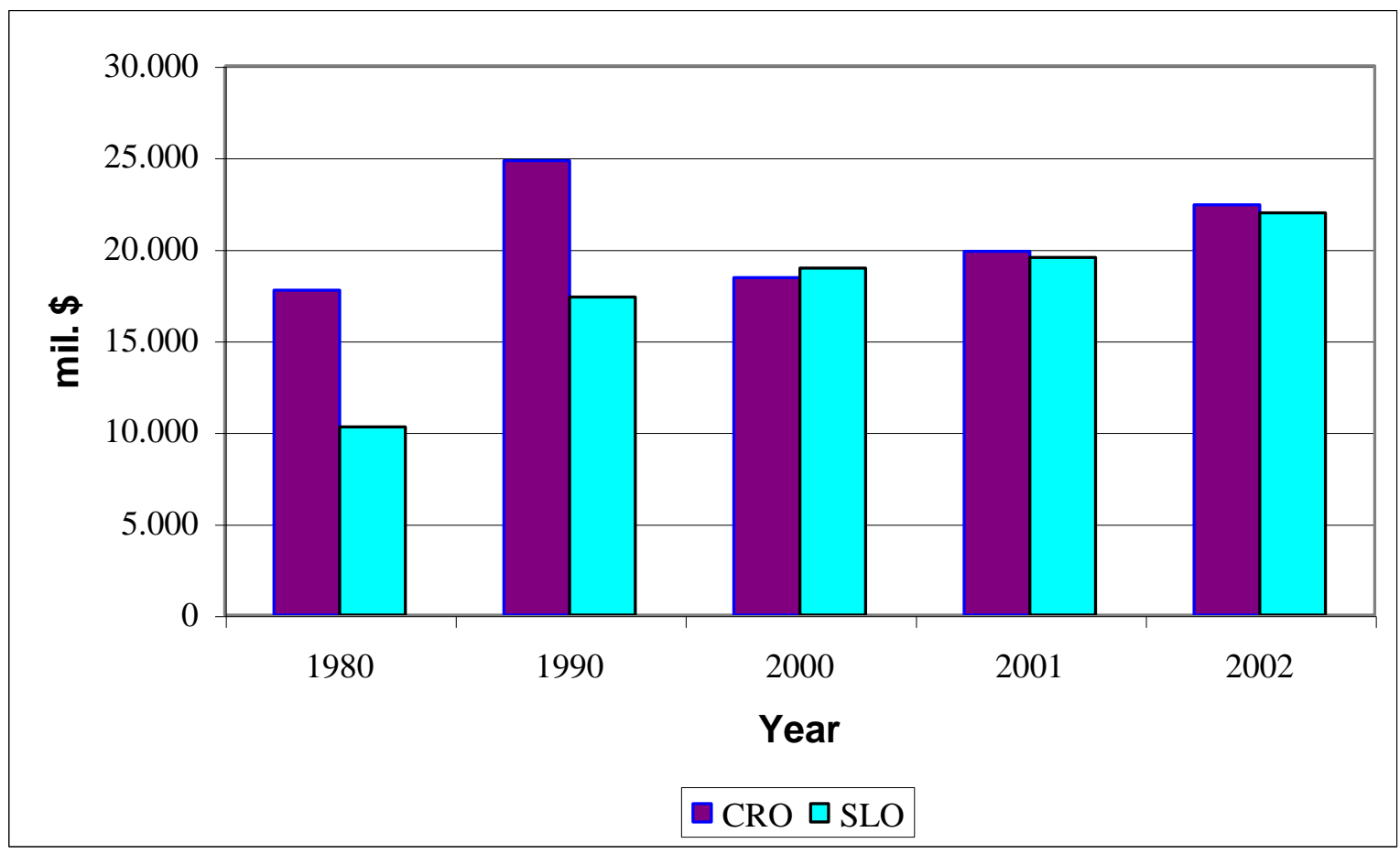

The differences between two countries that used to be part of the same state (ex Yugoslavia) could be explained with the structure of industry before and after privatization. The Slovenian industry was based on small and medium enterprises mostly in manufacturing and agriculture and now trades and services. Croatian industry was oriented to big manufacturing firms and shipyards, and tourism. Reproduction as a whole existed on the level of the Yugoslavian economy that had a negative impact on efficiency of many large and medium-sized enterprises in Croatia at the beginning of privatization. Thus, Croatian industry in the past was not nationally recognized. Additionally, war damage in Croatia is estimated at $\$ 37.1$ billion. 
Another difference of privatization and its effects are evident through results of enterprise performance. Furthermore, at the beginning of privatization, there was a prevailing belief that private ownership would be more efficient than the socially owned, and therefore would easily solve the problem of low efficiency by privatization. Otherwise, orientation to industrial production, research and development, employment rate, etc., was secondary. A serious problem was new management unprepared to the new conditions of the market economy. All these facts open a door to some illegal and controversial acts.

Furthermore, instead of improving some crucial large state enterprises, which are the base of a stable economy, the focus was given on the improvement of bank's sanitary conditions. For example, in Croatia, bank improvement was treated as public debt and cost $\$ 5.5$ billion and revenue of selling to foreign owners was $\$ 3.9$ billion. Monetary policy in Croatia is led with long-term stable "kuna" with appreciating currency that caused problems of too high imports and low exports of domestic goods. In both countries, economy is based mostly on trade and services. This makes a contribution to significant efficiency increases, especially in small enterprises, which grow by their numbers as realized revenues and net income. Their net income increased twice and revenue by 50 percent compared to the beginning of privatization. Lacking the previous state market, lagging technology, increase of import, lack of investment, lack of management knowledge and others have a negative impact on large and middle enterprises resulting in stagnation. In the last two years the beginning of investment cycle has some positive effects.

Through time series analyses and statistical approach it is confirmed that transformation from socially owned to private ownership is not the only prerequisite of better efficiency performance of enterprise. Ten-year period results of Croatian and Slovenian enterprises confirmed the placed hypothesis, as follows:

- $\quad$ First, privatization did not have the same effect on growth of all enterprises, i.e. the small enterprises operated more efficiently and effectively than the medium and large ones, especially in the mid-period of privatization which could be explained by higher demand than supply of goods, stable currency and banking policy.

- $\quad$ Second, in the long-term period the influence of small businesses to the whole industry is decreasing and stabilized on $1 / 3$ level of total economy. After a long period some foreign and domestic investments in industry have occurred, thus large and medium enterprises started to perform more efficiently than before.

- $\quad$ Third, efficiency and profitability as well as employment declined in the first year of privatization, but the tendency of growth is evident after 2000 in Croatia, while in Slovenia the continuous trend is present from the beginning of privatization.

- $\quad$ Fourth, through empirical study of two countries which did not follow the same privatization model it is confirmed that the model of privatization has impact on financial results of enterprises.

- $\quad$ Fifth, financial performance, particularly efficiency and profitability on along-term basis will have positive impact on macroeconomic growth in both countries.

\section{CONCLUSION}

Changing ownership marks the transition in Croatia and Slovenia, thus privatization was the main step to a market economy. Expectations from the privatization were very high, but from the beginning, the model of privatization was doomed to be unsuccessful and inadequate in Croatia. According to some opinions, Slovenia has chosen a more adequate model, treating all inhabitants equally by offering them shares in ownership. Comparing industrial growth before privatization of two countries, Croatia was more developed from the aspect of GDP. In addition, the consequences of the war in Croatia had negative influence on the development of economy as well as on the enterprises' performance. However, their common characteristic was rapid growth of small business, and after a period of stagnation, concurrently include a revival and restructuring of medium-sized and large enterprises. Their trend of growth was supported by foreign investment and a more stable banking system. From the beginning of the $20^{\text {th }}$ century large enterprises were recognized as the most powerful engines of progress (Shumpeter, 1942) and small and medium enterprises as providers of intermediate goods and services. 
On the case of Croatia and Slovenia it is confirmed that there is not only one answer to the question whether privatization has influence on enterprise efficiency or not, considering only the act of transformation to private ownership. The changing of ownership is not self-sufficient. Besides institutional and legal prerequisites, what is more important is to create an environment for restructuring industry and changing management behavior. The way of gaining ownership was essential in transitional countries, because investing their own resources implies better control of managing and achieving results. Thus, the model of privatization influences further micro and macroeconomic effects. The examples of performance in Croatia and Slovenia indicate that industry was efficient even before privatization and that privatization itself is a long and complex process. Research confirms the thesis that technological development, institutional and labor conditions, market, knowledge, and others have a more important role than the change in ownership alone. It is to be expected that concentrated privatization will have significantly better performance results.

\section{REFERENCES}

1. Bevan, A., Estrin, S., Schaffer, M., 1999: "Determinants of Enterprise performance during Transition", Center for Economic Reform and Transformation (CERT) Working Paper 99/03.

2. Bennett, J., Estrin, S., Maw, J., Urga, G. (2004): "Privatization Methods and Economic Growth", Journal of Economic Literature, February,

3. Djankov, S, Murrel, P., 2000: The Determinants of Enterprise Restructuring in Transition: An Assessment of the Evidence, The World Bank, Washington DC.

4. $\quad$ Doing Business in Croatia, Kogan Page, Ltd. London 1998.

5. Družić, G., 2003: Gospodarska i socijalna zbilja Hrvatske "The economy and social reality of Croatia", Ekonomska politika Hrvatske u 2004.

6. "Economy policy of Croatia in 2004", Review proceeding, Opatija 2003.

7. "Financial statement Industry of Republic of Slovenia for period 1993 to 2002", Agency for Payments, Ljubljana, 2002 Year Statistical book for Croatia and Slovenia

8. Havrylyshyn, O., McGettigan, 1999: "Privatization in Transition Countries: A Stratified Sampling of the Literture", IMF Working Paper, December

9. Hrovatin, N, Montanheiro, L, (1996): "Privatisation: Underlaying Policy issues Comparing Britain and Slovenia", International Conference Dedicated to the Fiftieth Anniversary of the Faculty of Economics, Ljubljana, Slovenia.

10. Information about financial results of enterprises in Republic of Croatia for period 1993 to 2002, Agency for Payments, Zagreb

11. Jensen, M.C, 2003: A Theory of the Firm: Governance, Residual Claims, and Organizational Forms, Harvard University Press.

12. Megginson, W. L., Netter, J. R, 2001: "From State to Market: A Survey of Empirical Studies on Privatization", Journal of Economic Literature 39; (2) 321-389, June 2001.

13. Privatization Report, Agency of the Republic of Slovenia for Restructuring and Privatization, November 1997.

14. Roland, G., 2000: Transition and Economics: Politics; Markets and Firms, Cambridge, MA: MIT Press.

15. Sachs, J, Zinnes, C., Eilat, Y., (2000): "The Gains from Privatization in Transition Economies: Is Change of Ownership Enough?", CAER II Discussion Paper 63, Harvard Institute for International Development, Vol. III.

16. Sappington, D., Stiglitz, J., 1987: "Privatization, information and incentives", Journal of Policy Analysis and Management, Vol. 6, pages 567-582.

17. Shirley, M., Walsh, P., 2000: Public versus Private Ownership: The Current State of the Debate. The World Bank, Washington, DC.

18. Shumpeter, J, 1942: Capitalism, Socialism and Democracy, New York: Harper and Row

19. Tearney, M., Vitezić, N. 1999: 'The Efficiency of Small Enterprises and Their Impact on Economic Development: A Case of Croatian and Slovenian Enterprises", Third International Conference, Enterprise in Transition, Split, Croatia, May, 1999. Pages 2256-2272.

20. Vitezić, N., Tearney, M.2001: "The Growth of Small Business: A Study of its Development in Croatia and Slovenia", Fourth International Conference "Enterprise in Transition", Split, Croatia, May 2001. Pages 2814-2827. 